IX.-NOTES.

The following gentlemen has joined the MIND Associstion since the printing of the July number:-

W. Oarmus, Hailie, Lipecomb, Surrey.

\title{
NOTES ON $\triangle$ NOTE.
}

There are some points of interest in Mr. Bradley's footnote on pege 498 of the last number of Mrro. As the note is whort I may as well quote it in full :-

"To the question if the above principle 18 merely 'practical,' I reply "Certainly, if you take " practice" so widely as to remove the distinotion between practioe and theory'. But, since such a widening of sense oms to serve no useful purpose, I cannot regard that course as being itself very 'practical'. I answer therefore that the above principle is oertainly not merely practical."

The impatient reader, if he understends what progmatism ls, will naturally be inolıned to dismise this footnote as nonsense. Here, he will say, is Ar. Bradley imagining a question put in language which no pragmatist would use-for to talk of the 'merely practical ' is to sasume that the 'more than practical ' existe. This question Mr. Bradley says he is ready to answer in the affirmstive if the questionor will etultify it by assuming that the 'more than preotical' does not exist. And then, after giving, irrelevantly, e reason for not being willing to ' remove' the distinotion between practioe and theory, Mr. Bradley proposes to answer the question with a simple negative-an angwer whioh avoids all explanations, and is therefore one whioh might equally well be made by a pragmatist on the ground of the talse assumption which the question implies. No wonder, the reader will say, that if this be a specimen of the efforts Mr. Bradley has made to disoover whether he " is and has alrays been " a pragmatist, he has hitherto failed to solve that simple problem.

But if wo are more patient we may get at some of the sources of Mr. Bradley's confusion. The word 'merely,' for instance, has evidently comething to do with it. One knows that the too free employment of this word is a common result of the (intellectualiat) habit of using abstract distinctions as if there could be no doubt sbout their sppliostion. Readers of Mns will remember some instances colleoted by Dr. Sohiller (N.S., No. 52, p. 528), in which Mr. Bradloy had gratuitously introduoed a 'mere' or a 'merely' into pragmatist doctrines, and had thereby givon a false account of them. If it had not been for his feint-hearted decision that Dr. Sohuller's writings should no longer "sttreot his sttention" he might by this time have loarnt his orror.

Another probable source of the confusion would also have been spoided by any one who hed ohoeen to instruot himself in the pragmatist writings. Buoh a reader would understand the slovenliness of any talk sbout 'removing' a distinction. He would bo famjliar with the viow that : distinction is always a tool with 8 use of some kind, but a tool that is also liable to be misueed; and that therefore the problem is to discriminato betwreen the use and abuse of it, to reeerve our trust in it for the ocoseions on which it is unlikely to mislend, and to oriticise so sharply as possiblo the use of it on any other occasions. Whether he agreed with this view 
or not, he would know that the praymatiat method is full of it. Praymatists do not first ' remove' a distinction, and then by an afterthought (if at all) ask whether euch removal serves any useful purpose; what they do is, first, to judge (rightly or wrongly) that for certain purposes, which the contert indicstes, a distınction otherwise useful does not hold good, and then to object to the use of the distunction for those purpoees and openly on that ground. The relevant way of answering this contention, therefore, is to attack the judgment involved $10 \mathrm{it}$, and not to pretend that the 'removal' has been suggested at random.

The pragmatiat has ullowed himself to recognise, quite generally, that the value of distinctions is lisble to vary with the varyng parposes for whioh they are used. Mr. Bradley, though here and there hie every one else ho may admit such varistions, seems for the most part more attuned to the easier view- the view encouraged also by formal loge-that questions about particular cawes are turesome and neglignble; so that a distinotion must be either valud or not valid, either kept and trusted or else 'removed'. A spade, wo all agree, is elther fit for use or fit for the dustheap; and the eesy, natural, abstract now of distinctions treats them in sumilar way.

On the whole, then, the footnote quoted above has some value throwing a further light on Mr. Bradley's controversial methods, and as therefore providing a further object-leseon in the wrys in which a controversy thould not be conduoted if a good effeot is desired. This may also help to remind us that though Mr. Bradloy is cartainly not yet a pragmatist, he has at least indirectly and unintentionally done a great deal for the advancement of the osuse.

ALFRed BIDG wick.

\section{THE ROOTS OF REALITY : REPLY.}

As Mr. Bex has directly challenged my criticism of his book, The Roots of Reality, I am porhape bound to reply, but my raply nood not take up much spece. For, as regands the first of the two issues to which he refers, I do not eee that his explanstion really removes my difficulty. He speeks of his primordial Subject as the " ultimate Matter of all perooption," and I can only repeat that a Matter which is the correlative of Form cannot also be prior to it, temporally or otherwiso-formleas matter being as unreal as mstterlews form. And, as regards the seoond issue, Mr. Bax' remarts are wholly besed on a misunderstanding, for which, however, I appear to be mysolf responsible. I did not mean to aseort any actual or peychological existence of the " unversal consciourness," snd apparontly I ought to have said so more explicitly. I merely used this conception as the simplest device for expresing the nature of knowledge so far a that nature is independent of the limitations inseparable from the finitude of the undividual knower. But I could have stated my criticiam will onough, I daresay, by saying that what is alogioal for $\mathbf{A}$ or $B$ here and now is not therefore destined to remain 80 for all men for all time ooming; or, aquin, by saying that we have no right to transfor, as we do if wo use such a notion as Chanos, the deficiencies of our knowlodge of reality to the reality iteelf. The "alogieal," in faot, reoms to be no more than a symbol for the limitations of actual knowledge. It was of course, for this reason that the "pricciple " sepmed to me " uneatiafectory" (though I do not use s phrase of this kind "more then onos") when offered as. solution of any concroto problom. And I quoted, though perhape without sufficient commentary, four applications of the prinoiple from which, I thought, the reader could judge for himself whether my subsequent axpresaion of opinios was justified.

H. BANCR 